\title{
Diet Comparison of Coexisting Collared Owlet (Glaucidium brodiei Burton, 1836), Spotted Owlet (Athene brama Temminck, 1821) and Eurasian Eagle Owl (Bubo bubo Linnaeus, 1758) in Wildlife Park Lohi Bher, Rawalpindi, Pakistan
}

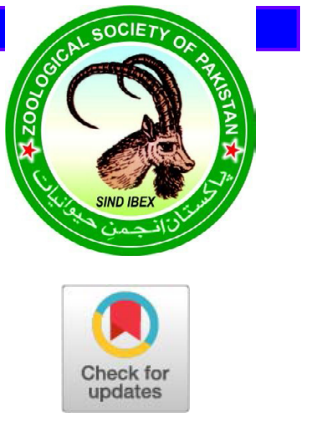

\author{
Muhammad Bilal Anwar', Mirza Azhar Beg', Amjad Rashid Kayani', \\ Muhammad Sajid Nadeem ${ }^{*}$, Syed Israr Shah', Sajida Noureen ${ }^{2}$, \\ Muhammad Mushtaq ${ }^{1}$ and Tariq Mahmood ${ }^{3}$ \\ ${ }^{1}$ Department of Zoology, PMAS-Arid Agriculture University, Rawalpindi \\ ${ }^{2}$ Department of Forestry and Wildlife Management, The University of Haripur, Haripur, \\ Khyber Pakhtunkhwa 22620 \\ ${ }^{3}$ Department of Wildlife Management, PMAS-Arid Agriculture University, Rawalpindi
}

\begin{abstract}
A B S T R A C T
The collared owlet (Glaucidium brodiei), spotted owlet (Athene brama) and eurasian eagle owl (Bubo bubo) are different sized avian predators coexisting in the Wildlife Park Lohi Bher, Rawalpindi district of the Punjab province of Pakistan. These crepuscular and nocturnal owls are the least studied group of birds in northern regions. In this study, we compared seasonal differences in the diet of three owl species in an uncultivated area with rapid urbanization all around to better understand their ecological significance. Regurgitated pellets of three owl species $(n=434)$ were collected seasonally from the study area. The food of the spotted owlet and eurasian eagle owl was found significantly different $(P<0.05)$ across seasons whereas no seasonal differences were seen in collared owlet's prey resources. Insects of four orders dominated in the diet of collared owlet (50\%) and spotted owlet $(56.62 \%)$ whereas the major portion of the food of eurasian eagle owl was obtained from mammals $(75.93 \%)$ in numerical terms. Among mammals, house mouse Mus musculus, Asian house shrew Suncus murinus, short-tailed bandicoot rat Nesokia indica and Indian gerbil Tatera indica were the prominent food sources. Food niche breadth of the eurasian eagle owl was larger as compared to the other two owlet species. Index of relative importance (IRI) values highlighted rodents as staples in the three owls' diets in contrast to conventional proportional representations. An inverse relationship between the body size of owls and preys suggested prey selection might be associated with ecological dynamics in prey populations.
\end{abstract}

\author{
Article Information \\ Received 14 December 2019 \\ Revised 23 February 2020 \\ Accepted 04 March 2020 \\ Available online 30 March 2021 \\ Authors' Contribution \\ MBA wrote the manuscript and \\ conducted field work. MAB provided \\ concept and designed the study. ARK \\ SIS and SN joined the field surveys \\ and help in analysis. MSN supervised \\ the study and edit the manuscript. \\ MM and TM prepared figures and \\ analyzed the data. \\ Key words \\ Glaucidium brodiei, Athene brama, \\ Bubo bubo, Collared owlet, Spotted \\ owlet, Eurasian eagle owl
}

\section{INTRODUCTION}

$\mathrm{T}^{\mathrm{s}}$ he ecological distribution of predatory bird populations considerably relies on quality and quantity of prey species in terms of both space and time (Kayahan and Tabur, 2016). Primary segregation among coexisting predators highlights behavioural adaptations that minimize conflicts between competitive species, for example diurnal and nocturnal habits of predation (Aragón et al., 2002; Cichocki et al., 2008). Many features of prey species including age and size, accessibility and availability, and distribution patterns resolve interspecific competition among predators (Capizzi and Luiselli, 1998;

\footnotetext{
Corresponding author: sajidnm@uaar.edu.pk 0030-9923/2021/0003-1065 \$ 9.00/0

Copyright 2021 Zoological Society of Pakistan
}

Balčiauskas and Balčiauskienè, 2014). There is a positive relationship between predator body size and prey body size within a food web (Cohen et al., 1993). Trejo and Guthmann (2003) studied the diet of magellanic-horned owl (Bubo magellanicus) and concluded that the owls captured preys of small size. Excessive dietary overlap occurs in coexisting owls of same size because of predation on prey species of same size whereas variable body sized sympatric owls consume preys of different body mass with decreased dietary overlap (Jaksić, 1982; Hayward and Garton, 1988). Food-niche separation among predators depends on the size of prey species (Nakazawa, 2017). Seasons and habitats have pronounced influence on the food selection of owls as accessibility towards prey may vary accordingly. Seasonal comparison between different owl species can enhance our knowledge about the ecology of nocturnal avian predators (Mehta et al., 2018). 
In Pakistan, owl researchers focused on the diet of barn owl Tyto alba because of its broader food niche and agricultural importance as a rodent pest-controlling agent. Only a few planned studies (Mushtaq-ul-Hassan et al., 2007; Nadeem et al., 2012) described trophic interactions of coexisting owls in Balochistan and southern Punjab. In the present study, we focused on three coexisting owls in northern Punjab, Pakistan i.e. collared owlet (Glaucidium brodiei), spotted owlet (Athene brama) and eurasian eagle owl (Bubo bubo). All the three owl species have wide distribution throughout Indo Malayan and Palaearctic regions with marked differences in the ecology, morphology, breeding and activity times (Birdlife International, 2018). The collared owlet is the smallest crepuscular owl species (body length $=16-20 \mathrm{~cm}$, body weight $=52-63 \mathrm{~g}$ ), breeds during May-July and resides in Himalayan region with altitudinal migrations to foothills of Himalayas (Roberts, 1991; Konig and Weick, 2008). Until now, no detailed study has existed on the food habits of the collared owlet in Pakistan.

The spotted owlet is a little crepuscular or nocturnal owl species (body length $=21-25 \mathrm{~cm}$, body weight $=110$ $115 \mathrm{~g}$ ), has been observed breeding from February to April (Ali and Ripley, 1987; Roberts, 1991; Mahmood-ulHassan et al., 2007a) and residing in a variety of habitats scattered all over Pakistan (Roberts, 1991). Food of spotted owlet studied in plains of Punjab province (Akhtar and Beg, 1985; Beg et al., 1990; Mushtaq-ul-Hassan et al., 2003, 2007b; Shah et al., 2004; Nadeem et al., 2012) and Sindh province (Tariq et al., 2003). However, dietary information of the spotted owlet in northern parts of Punjab province is scanty.

The eurasian eagle owl is large-sized nocturnal owl (body length $=56-72 \mathrm{~cm}$, body weight $=2100-3260 \mathrm{~g}$ ) that has wide distribution across Pakistan with a resident status and it breeds from November to early December (Roberts, 1991; Konig and Weick, 2008). The literature on dietary habits of eurasian eagle owl from Pakistan is also scarce.

The aim of the present investigation was to scrutinize the food synchronization, seasonal differences, and niche breadth/overlap in the diet of three co-existing varied sized owls in Wildlife Park Lohi Bher, Rawalpindi district of northern Punjab. Since owls' nests were located in the uncultivated natural habitat surrounded by extensive human settlements, we hypothesized that their seasonal food might be dominated by wild prey species.

\section{MATERIALS AND METHODS}

\section{Study area}

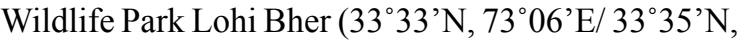
$\left.73.09^{\prime} \mathrm{E}\right)$ is located on Islamabad Express Highway to the southeast of Islamabad Capital Territory of Pakistan. The park was proposed during 1988 in Lohi Bher forest reserve at Margalla Piedmont zone of Rawalpindi district and was opened for public in 1992. The area of the park is approximately 278 hectares sprawling along the left bank of Korang River (Fig. 1A). The park represents flat to undulating topography with altitudinal variations ranging from 427-490 $\mathrm{m}$ above mean sea level (Fig. 1B). Generalized weather conditions of the area range from the semi-arid to sub-humid showing of hot and long summer, monsoon season, and freezing wet winter. During the study period, highest temperature was observed in May and June $\left(22-42^{\circ} \mathrm{C}\right)$ while December and January (0$21^{\circ} \mathrm{C}$ ) were the coldest months of the winter. Average annual precipitation was recorded $83.5 \mathrm{~mm}(0-322 \mathrm{~mm})$ with heavy rainfall in the monsoon months of July and August (PMD, 2015). Despite rapid urbanization in the park vicinity, the area represents high wilderness and is hospitable to many wild species of plants and animals. The park lies in region with related plant species of Adhatoda vasica, Anagallis arvensis, Cannabis sativa, Cymbopogon jwarancusa, Cynodon dactylon, Desmostachya bipinnata, Nerium oleander, Prosopis glandulosa, Solanum nigrum and Ziziphus mauritiana (Ahmad and Ehsan, 2012; Kayani et al., 2015). Wildlife Park Lohi Bher supports a variety of wild animals including mammals and birds. Prominent wild mammal species are Asiatic jackal (Canis aureus), porcupine (Hystrix indica), small Indian mongoose (Herpestes javanicus auropunctatus), hedgehog (Hemiechinus collaris), Indian hare (Lepus nigricollis) and pangolin (Manis crassicaudata) (Roberts, 1997). Common resident birds of the region are black drongo (Dicrurus macrocercus), common myna (Acridotheres tristis), jungle crow (Corvus macrorhynchos), red-wattled lapwing (Vanellus indicus), eurasian collared dove (Streptopelia decaocta), white-throated kingfisher (Halcyon smyrnensis) and tree pie (Dendrocitta vagabunda) (Roberts, 1991).

\section{Pellet collection and analysis}

Exploratory visits were made during May 2012 and regular seasonal/monthly visits were made by two persons during 0700 hours through 1900 hours from June 2012 to September 2015 for owls' pellet collection in the study area. We distributed months into four seasons namely winter (December-February), spring (MarchMay), summer (June-August) and autumn (SeptemberNovember). Pellets collected during the study period were pooled seasonally to know the seasonal variations in owls' diet. Owl nests and roosting sites were found by direct searching, questioning wildlife watchers and guards of the park, and other related indirect signs including remains of prey, white excrement (Zuberogoitia, 2002), size and 
shape of pellets. Owls were spotted using binoculars and identified by direct sighting. Each nesting site was given a name, based on the residing owl species (Fig. 1A). The nesting coordinates were recorded by using handheld GPS (Garmin GPS 60CS). Once nesting site and owl species were identified, only fresh and intact pellets were collected seasonally. In the field, pellets were temporarily stored in sealable polythene bags separately by labelling necessary information including identification number, date, site of collection and owl species on a tag.

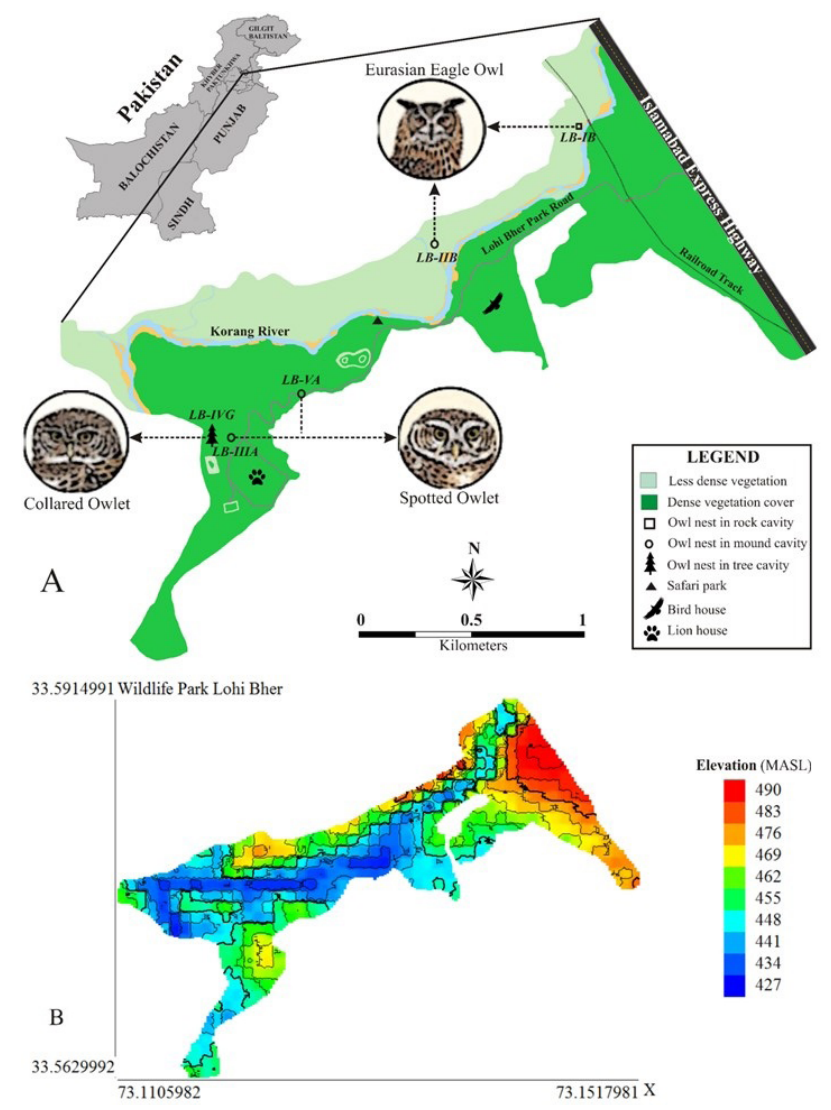

Fig. 1. Map of the Wildlife Park Lohi Bher in Rawalpindi district showing nesting sites of the collared owlet, spotted owlet and eurasian eagle owl (A) with contour map showing different elevation levels at MASL (B).

In the laboratory, pellets were oven dried at $50{ }^{\circ} \mathrm{C}$ overnight. The linear measurements of length and breadth were measured by digital vernier calliper with an accuracy of $0.01 \mathrm{~mm}$. All pellets were weighed using an electronic laboratory balance (TX323L Shimadzu) with an accuracy of $0.01 \mathrm{~g}$. Before analysis, pellets were soaked overnight in mellow water. The pellet contents were carefully disentangled with tweezers and were properly washed. Using dissection microscope (XSJ-II), the prey items were segregated primarily into invertebrate and vertebrate contents. Insects were identified up to the order level by chitinous parts of elytra, genitalia, head, legs, mandibles, pedipalps, patellae of appendages, pincers, proboscis and sting exuviae. Mammals among vertebrates were identified to species level by characteristics of hairs, crania, dental patterns, and mandibular shapes and placed in groups of murid rodents, insectivores, lagomorph, carnivores and chiroptera. Beaks, bones, bird claws, feathers, keels and skulls, ascertained avian remnants whereas reptiles were determined by claws, jaws and skin scales. Where identification was not possible up to the genus or order level, we placed that item into the unidentified category of relevant taxon. We counted prey items by following Marti et al. (2007).

\section{Comparative significance of prey items}

We present data as relative abundance of prey items $(\% N)$ and percent biomass consumed $(\% B)$. Abundance was calculated by tallying each prey item in the owls' diet. To know the relative abundance of each prey item, tally values were divided by sum of all prey items and multiplied with 100. Biomass was calculated by multiplying the number of prey items found in pellets to the mean prey mass of that prey item and multiplied with 100 to express it as percent biomass. Mass of mammals and birds was taken from relevant literature (Roberts, 1991, 1997; Qureshi et al., 2012). Each insect found in the pellets of owls was allotted a weight of one gram (Leonardi and Arte, 2006). Dietary items consumed by different individuals in small amounts may show high occurrence with least importance. An integrative approach to minimize bias in the measurement of predators' diet is the index of relative importance (IRI), first practical application was proposed by Pinkas (1971). In this study, we used modified equation of IRI by Martin et al. (1996), where volumetric percentage was replaced with percent biomass. Hart et al. (2002) used this method for barn owl diet estimation that can also be used for other raptors as well (Marti et al., 2007). Index values were calculated for known taxa of prey items in each owl's diet by following equation: $\mathrm{IRI}=(\mathrm{N}+\mathrm{W}) \mathrm{F}$ where $\mathrm{N}$ is the relative abundance $(\% \mathrm{~N}), \mathrm{W}$ is the percent biomass $(\% \mathrm{~B})$ and $F$ is the percent frequency of occurrence $(\% \mathrm{~F})$ i.e. the number of owl pellets consisting of a prey item.

We recorded seasonal variations/diversity of prey species in the food through Shannon-Wiener index (H') (Shannon, 1948) by employing the following equation:

$$
\mathrm{H}^{\prime}=-\sum_{\mathrm{i}=1}^{\mathrm{s}}\left(\mathrm{P}_{\mathrm{i}}\right)\left(\log _{\mathrm{e}} \mathrm{P}_{\mathrm{i}}\right)
$$

Where $\mathrm{H}^{\prime}$ is the diversity of prey species, $s$ the number 
of prey species and $\mathrm{P}_{\mathrm{i}}$ is the proportion of individuals in the total sample belonging to the $\mathrm{i}^{\text {th }}$ prey species. We measured the equitability of prey communities in the seasonal diet of owl species by Pielou's evenness index (J') (Pielou, 1966).

$$
\mathrm{J}^{\prime}=\frac{\mathrm{H}^{\prime}}{\mathrm{In}(\mathrm{S})}
$$

Where $\mathrm{H}^{\prime}$ is the number derived from the shannonwiener index, and $\mathrm{S}$ is the total number of prey species.

Mean biomass of prey produced errors due to very large and very small prey species. To reduce problems associated with this condition we calculated geometric mean prey weight (GMPW) by following Marti et al. (2007)

$$
\mathrm{GMPW}=\operatorname{anti} \log \left[\frac{\sum \mathrm{n}_{\mathrm{i}} \log _{\mathrm{e}} \mathrm{w}_{\mathrm{i}}}{\sum \mathrm{n}_{\mathrm{i}}}\right] \pm \mathrm{SEM}
$$

Where $n_{i}$ is the number of the prey individual $i$ and $w_{i}$ is the average mass of prey individual i. GMPW values were represented along with \pm standard error of mean (SEM). The quantitative assessment of the hunting specializations of owl species was done by measuring food niche breadth (FNB) following Levins (1968).

$$
\mathrm{B}=\frac{1}{\sum \mathrm{p}_{\mathrm{i}}^{2}}
$$

Where $\mathrm{P}_{\mathrm{i}}$ is the proportion of individual $\mathrm{i}$ by means of frequency. This measure of food niche breadth was standardized $\left(\mathrm{FNB}_{\mathrm{S}}\right)$ on $0-1$ scale by following Hurlbert (1978).

$$
\mathrm{B}_{\mathrm{A}}=\frac{\mathrm{B}-1}{\mathrm{n}-1}
$$

Where $\mathrm{n}$ is the total number of prey items identified in the owl pellets.

To understand the seasonal dietary overlap of prey species in the diet of owl species, we calculated dietary overlap by following Pianka (1973). The values of dietary overlap $\left(\mathrm{O}_{\mathrm{i}, \mathrm{j}}\right)$ were multiplied by 100 to convert them as percentages by following Mehta et al. (2018).

$$
\text { PrecentO }_{i, j}=\left[\frac{\sum_{i}^{n} P_{i, j} P_{i, k}}{\sum_{i}^{n} P_{i, j}^{2} \sum_{i}^{n} P_{i, k}^{2}}\right] \times 100
$$

Where $\mathrm{P}_{\mathrm{i}, \mathrm{i}}$ is proportion of prey species $\mathrm{i}$ in the total prey species used by an owl species $\mathrm{j}$ and $\mathrm{P}_{\mathrm{i}, \mathrm{k}}$ is the proportion of prey species $i$ in the total prey species used by owl species $\mathrm{k}$.

\section{Statistical analysis}

Analysis by Kolmogorov-Smirnov test revealed the non-normal distribution of data, as experienced in raptor food habit studies (Marti et al., 2007). We observed variations in seasonal diet consumption of an owl species and dietary variations among owl species by KruskalWallis $(\mathrm{H})$ test and paired comparison of means was performed with Mann-Whitney (U) test. For comparison of geometric means, we used Student's t-test. All pair-wise comparisons were two-tailed and significance was set at 0.05 . The statistical package for windows (IBM, SPSS version 24) was used for these statistical procedures.

\section{RESULTS}

From 63 pellets of the collared owlet, 132 prey items were recorded. The mean pellet length was $21.77 \mathrm{~mm}$ $(\mathrm{SEM} \pm 0.76$, range $=14.07-57.71 \mathrm{~mm})$ with mean breadth of $10.95 \mathrm{~mm}(\mathrm{SEM} \pm 0.20$, range $=7.70-15.07 \mathrm{~mm})$ and the mean weight $0.59 \mathrm{~g}(\mathrm{SEM} \pm 0.04$, range $=0.32$ $2.62 \mathrm{~g}$ ) (Fig. 2A, B, C). Significant seasonal variations in the parameters of the pellet viz., pellet length $\left(\chi^{2}(3)\right.$ $=27.222, P<0.05)$, pellet breadth $\left(\chi^{2}(3)=9.228, P<\right.$ $0.05)$ and the pellet weight $\left(\chi^{2}(3)=16.130, P<0.05\right)$ were observed. The overall contribution of murids to the annual diet of the collared owlet was $40.91 \%$ (Table I). Of all the four species of murid rodents that were eaten by the collared owlet in the study area, only house mouse were eaten intensively in all the four seasons (Table II). The shrew was also eaten by the owlet in all the four seasons but it was not consumed as intensively as were the mice; its contribution to the owlet's diet was $6.82 \%$ only (Table I). Insects and scorpions accounted for $50.76 \%$ of the owlet's diet. Bulk of the biomass $(80.04 \%)$ of the diet of the collared owlet was due to four groups of rodents, Indian gerbil being the major contributor. The remaining biomass of the owlet's diet was due to shrews $(16.54 \%)$, insects $(3.36 \%)$ and scorpions $(0.06 \%)$ (Table I). A Kruskal-Wallis $(\mathrm{H})$ test reflected no significant differences in the diet of the collared owlet across seasons $\left(\chi^{2}(3)=0.418, P>0.05\right)$. The index of relative importance values suggested house mouse and insects of order Hymenoptera as prominent items in annual diet of the collared owlet (Table I).

We identified a total of 461 prey remnants from 282 pellets of the spotted owlets (Table III). The mean pellet length was $23.38 \mathrm{~mm}(\mathrm{SEM} \pm 0.40$, range $=10.87-41.03$ $\mathrm{mm})$, breadth $11.70 \mathrm{~mm}(\mathrm{SEM} \pm 0.14$, range $=7.16-22.21$ $\mathrm{mm}$ ) and the mean weight of pellets $0.86 \mathrm{~g}$ (SEM \pm 0.02 , range $=0.31-1.78 \mathrm{~g}$ ) (Fig. 2). Seasonal variation was significant in the case of pellet length $\left(\chi^{2}(3)=12.870, P<\right.$ $0.05)$ and pellet weight $\left(\chi^{2}(3)=37.642, P<0.05\right)$ whereas no seasonal differences were observed for pellet breadth $\left(\chi^{2}(3)=27.222, P<0.05\right)$. Between two rodent species (Table I), only the mice were eaten more intensively $(37.53 \%)$ during all seasons while short-tailed mole rat 
Table I. Relative abundance (\% N), biomass (\% B) and frequency of occurrence (\% F) of prey items consumed by the collared owlet $(n=63)$, spotted owlet $(n=282)$ and eurasian eagle owl $(n=89)$ along with index of relative importance (IRI)values in the Wildlife Park Lohi Bher, Rawalpindi District, Pakistan.

\begin{tabular}{|c|c|c|c|c|c|c|c|c|c|c|c|c|c|}
\hline \multirow[t]{2}{*}{ Prey items } & \multirow[b]{2}{*}{$\begin{array}{l}\text { Scientific } \\
\text { names }\end{array}$} & \multicolumn{4}{|c|}{ collared owlet } & \multicolumn{4}{|c|}{ spotted owlet } & \multicolumn{4}{|c|}{ Eurasian eagle owl } \\
\hline & & $\% \mathrm{~N}$ & $\% \mathrm{~B}$ & $\% \mathbf{F}$ & IRI & $\% \mathrm{~N}$ & $\% \mathrm{~B}$ & $\% \mathrm{~F}$ & IRI & $\% \mathrm{~N}$ & $\%$ B & $\% \mathbf{F}$ & IRI \\
\hline \multicolumn{14}{|l|}{ Murids rodents } \\
\hline Bandicoot rat & $\begin{array}{l}\text { Bandicota } \\
\text { bengalensis }\end{array}$ & 0.00 & 0.00 & 0.00 & 0.00 & 0.00 & 0.00 & 0.00 & 0.00 & 7.20 & 17.64 & 7.10 & 150.99 \\
\hline Indian bush rat & Golunda ellioti & 2.27 & 7.42 & 2.31 & 22.37 & 0.00 & 0.00 & 0.00 & 0.00 & 3.47 & 2.43 & 4.32 & 18.07 \\
\hline Indian gerbil & Tatera indica & 6.06 & 38.88 & 6.15 & 276.58 & 0.00 & 0.00 & 0.00 & 0.00 & 12.90 & 17.73 & 14.20 & 344.17 \\
\hline Short-tailed bandicoot rat & Nesokia indica & 0.76 & 7.80 & 0.77 & 6.58 & 0.43 & 9.76 & 0.47 & 4.82 & 13.15 & 28.98 & 12.96 & 461.82 \\
\hline Roof/house rat & Rattus rattus & 0.00 & 0.00 & 0.00 & 0.00 & 0.00 & 0.00 & 0.00 & 0.00 & 1.74 & 2.95 & 2.16 & 8.28 \\
\hline Mouse & Mus musculus & 31.82 & 25.94 & 32.31 & 1865.96 & 37.53 & 66.88 & 40.66 & 4245.27 & 22.83 & 3.98 & 15.74 & 244.19 \\
\hline \multicolumn{14}{|l|}{ Insectivores } \\
\hline Etruscan pygmy shrew & Suncus etruscus & 1.52 & 0.18 & 1.54 & 2.61 & 0.00 & 0.00 & 0.00 & 0.00 & 0.00 & 0.00 & 0.00 & 0.00 \\
\hline House shrew & Suncus murinus & 5.30 & 16.36 & 5.38 & 116.65 & 1.52 & 10.24 & 1.65 & 19.46 & 14.64 & 9.67 & 13.89 & 237.00 \\
\hline \multicolumn{14}{|l|}{ Lagomorph } \\
\hline Indian hare & $\begin{array}{l}\text { Lepus nigri- } \\
\text { collis }\end{array}$ & 0.00 & 0.00 & 0.00 & 0.00 & 0.00 & 0.00 & 0.00 & 0.00 & 0.50 & 14.10 & 0.62 & 8.86 \\
\hline \multicolumn{14}{|l|}{ Carnivore } \\
\hline Small Indian mongoose & $\begin{array}{l}\text { Herpestes } \\
\text { javanicus }\end{array}$ & 0.00 & 0.00 & 0.00 & 0.00 & 0.00 & 0.00 & 0.00 & 0.00 & 0.25 & 2.32 & 0.31 & 0.76 \\
\hline \multicolumn{14}{|l|}{ Chiropteran } \\
\hline Unknown microbats & & 0.00 & 0.00 & 0.00 & 0.00 & 0.00 & 0.00 & 0.00 & 0.00 & 0.50 & 0.00 & 0.62 & 0.00 \\
\hline \multicolumn{14}{|l|}{ Reptile } \\
\hline Unknown lizard & & 0.00 & 0.00 & 0.00 & 0.00 & 0.22 & 0.00 & 0.24 & 0.00 & 4.96 & 0.00 & 5.86 & 0.00 \\
\hline \multicolumn{14}{|l|}{ Birds } \\
\hline House Sparrow & $\begin{array}{l}\text { Passer domes- } \\
\text { ticus }\end{array}$ & 0.00 & 0.00 & 0.00 & 0.00 & 1.30 & 4.79 & 1.42 & 8.64 & 0.00 & 0.00 & 0.00 & 0.00 \\
\hline Unknown bird & & 0.00 & 0.00 & 0.00 & 0.00 & 0.22 & 0.00 & 0.24 & 0.00 & 2.73 & 0.00 & 3.40 & 0.00 \\
\hline \multicolumn{14}{|l|}{ Invertebrates } \\
\hline Coleoptera & & 7.58 & 0.51 & 7.69 & 62.20 & 37.74 & 5.55 & 33.57 & 1453.52 & 8.19 & 0.12 & 10.19 & 43.32 \\
\hline Hemiptera & & 9.09 & 0.61 & 7.69 & 74.64 & 9.98 & 1.47 & 9.69 & 110.95 & 0.00 & 0.00 & 0.00 & 0.00 \\
\hline Hymenoptera & & 31.06 & 2.09 & 31.54 & 1045.55 & 4.56 & 0.67 & 4.96 & 25.94 & 4.47 & 0.06 & 5.56 & 12.89 \\
\hline Orthoptera & & 2.27 & 0.15 & 2.31 & 5.60 & 4.34 & 0.64 & 4.73 & 23.53 & 0.50 & 0.01 & 0.62 & 0.16 \\
\hline Scorpiones & & 0.76 & 0.06 & 0.77 & 0.62 & 0.00 & 0.00 & 0.00 & 0.00 & 0.00 & 0.00 & 0.00 & 0.00 \\
\hline $\begin{array}{l}\text { Unidentified inverte- } \\
\text { brates }\end{array}$ & & 0.00 & 0.00 & 0.00 & 0.00 & 2.17 & 0.00 & 2.36 & 0.00 & 0.00 & 0.00 & 0.00 & 0.00 \\
\hline Unidentified plant matter & & 1.52 & 0.00 & 1.54 & 0.00 & 0.00 & 0.00 & 0.00 & 0.00 & 1.99 & 0.00 & 2.47 & 0.00 \\
\hline
\end{tabular}

was occasionally consumed in summer and winter seasons (Table III). House shrew was eaten in the winter, summer and autumn seasons and accounted for only $1.52 \%$ of prey remnants. Contribution of lizards and birds was also occasional being only $1.74 \%$. However, insects, particularly beetles jointly accounted for $56.42 \%$ of the owlet's diet (Table I). About $76.64 \%$ of the prey biomass in the annual diet of the owlet was due to two murids; viz., short-tailed mole rat $(9.76 \%)$ and house mouse being the chief source $(66.88 \%)$. Rest of the biomass of the owlet's diet was due to house shrew $(10.24 \%)$, birds $(4.79 \%)$, and insects $(8.33 \%)$ (Table I). Significant seasonal variation 
was observed in consumption of prey resources, $\chi^{2}$ (3) $=12.972, P<0.05$ with a mean rank prey item score of 248.62 for winter, 222.51, spring, 255.25, summer and 198.51 for autumn. Though winter and spring diets were not significantly different $(\mathrm{U}=8195, \mathrm{P}=0.084)$, spring and summer $(\mathrm{U}=5736, \mathrm{P}=0.041)$, summer and autumn $(\mathrm{U}=3349, \mathrm{P}=0.003)$ and winter and autumn $(\mathrm{U}=4771, \mathrm{P}=$ $0.004)$ prey items varied significantly. The values of IRI ranked house mouse as most staple food item and it was supplemented with beetles of the order Coleoptera.
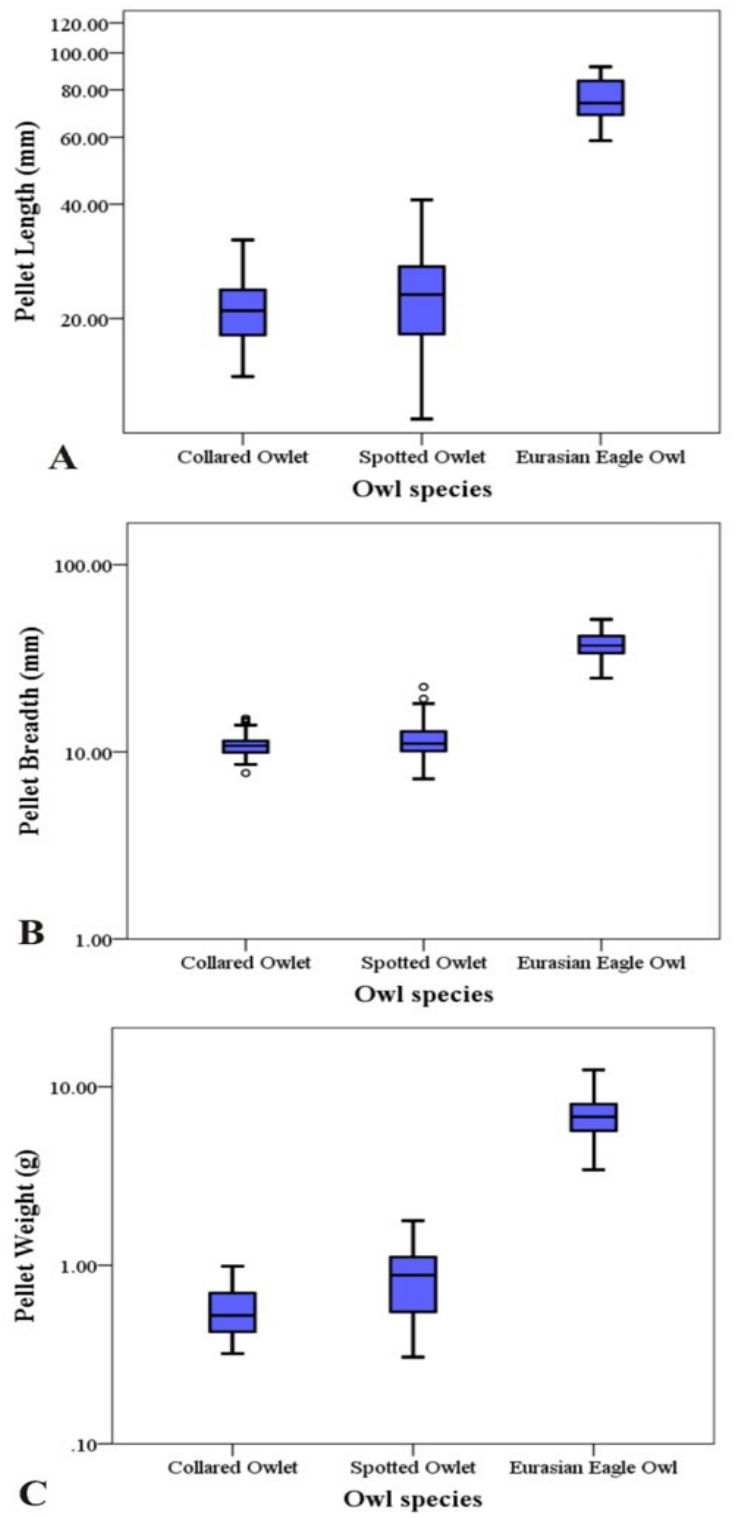

Fig. 2. A comparison of the length (A), breadth (B) and weight (C) of the pellets of the collared owlet, spotted owlet and eurasian eagle owl showing medians, upper and lower quartiles and sample ranges.

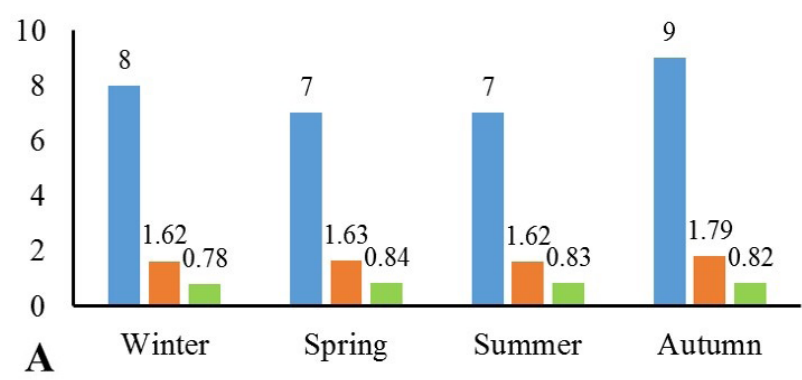

Richness $=\mathrm{S} \backsim$ Shanon-Wiener Index $\left(\mathrm{H}^{\prime}\right) \approx$ Peilou's eveness $(J)$

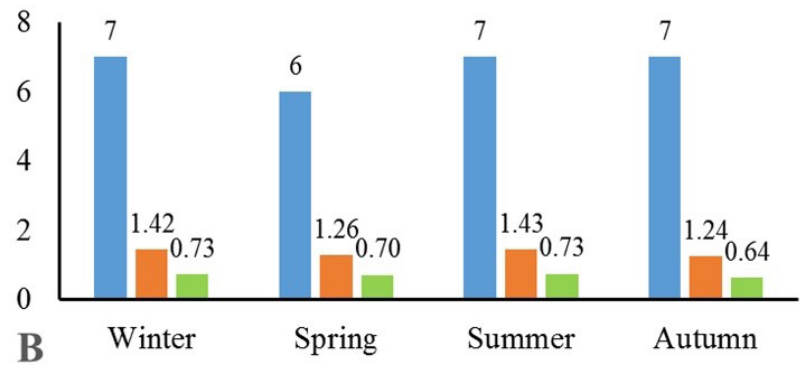

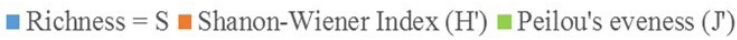

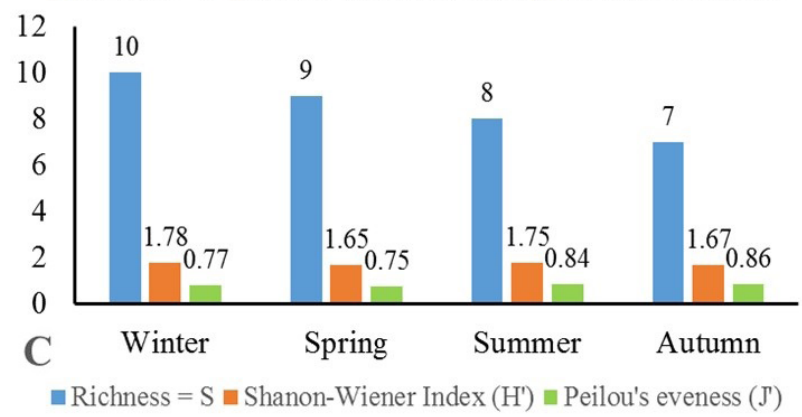

Fig. 3. Seasonal diversity of prey species in the diet of collared owlet (A), spotted owlet (B) and eurasian eagle owl (C) in Lohi Bher.

From a total of 89 pellets of eurasian eagle owl, we identified a total of 403 prey items. The mean length of the pellets was $76.14 \mathrm{~mm}(\mathrm{SEM} \pm 0.99$, range $=58.72-91.97$ $\mathrm{mm})$, mean breadth $38.06 \mathrm{~mm}(\mathrm{SEM} \pm 0.56$, range $=24.73$ $50.99 \mathrm{~mm})$, and the mean weight $6.85 \mathrm{~g}(\mathrm{SEM} \pm 0.19$, range $=3.43-12.42 \mathrm{~g}$ ) (Fig. 2). All parameters of pellet length $\left(\chi^{2}(3)=216.197, P<0.05\right)$, breadth $\left(\chi^{2}(3)=113.494\right.$, $P<0.05)$ and weight $\left(\chi^{2}(3)=81.764, P<0.05\right)$ were significantly different during four seasons. Murid rodents were the chief staples of the diet of eagle owl in all the four seasons (Table IV). Three species, namely House mouse $(22.83 \%)$, mole rat $(13.15 \%)$ and Indian gerbil $(12.90 \%)$ were the most consumed murids among the six species represented in the owl's pellets (Table I). The murids were most intensively eaten during the summer season (78.95\%) and least during the winter season (50.00\%) (Table IV). Among the other mammalian prey species, 
Table II. Seasonal variations in relative abundance $(\% \mathrm{~N})$ and biomass $(\% \mathrm{~B})$ of prey items in the food of the collared owlet (Glaucidium brodiei) from Wildlife Park Lohi Bher, Rawalpindi District, Pakistan.

\begin{tabular}{|c|c|c|c|c|c|c|c|c|c|}
\hline \multirow[t]{2}{*}{ Prey Items } & \multirow{2}{*}{$\begin{array}{l}\text { Mean Prey } \\
\text { Mass (g) }\end{array}$} & \multicolumn{2}{|c|}{ Winter } & \multicolumn{2}{|c|}{ Spring } & \multicolumn{2}{|c|}{ Summer } & \multicolumn{2}{|c|}{ Autumn } \\
\hline & & $\% \mathbf{N}$ & $\% \mathrm{~B}$ & $\% \mathrm{~N}$ & $\%$ B & $\% \mathbf{N}$ & $\% \mathrm{~B}$ & $\% \mathbf{N}$ & $\% \mathrm{~B}$ \\
\hline Mammals & & 46.67 & 95.92 & 47.05 & 96.52 & 45.83 & 95.62 & 51.72 & 97.69 \\
\hline Rodents & & 40.00 & 86.75 & 41.17 & 78.84 & 37.50 & 64.74 & 44.83 & 82.58 \\
\hline -Indian bush rat & 48.5 & 0.00 & 0.00 & 5.88 & 18.71 & 0.00 & 0.00 & 3.45 & 7.99 \\
\hline -Indian gerbil & 95.31 & 6.67 & 53.05 & 5.88 & 36.77 & 4.17 & 32.11 & 6.90 & 31.42 \\
\hline -Short-tailed bandicoot & 152.91 & 0.00 & 0.00 & 0.00 & 0.00 & 0.00 & 0.00 & 3.45 & 25.20 \\
\hline -House mouse & 12.11 & 33.33 & 33.70 & 29.41 & 23.36 & 33.33 & 32.64 & 31.03 & 17.96 \\
\hline Shrews & & 6.67 & 9.17 & 5.88 & 17.68 & 8.33 & 30.88 & 6.90 & 15.11 \\
\hline Etruscan pygmy shrew & 1.8 & 4.44 & 0.67 & 0.00 & 0.00 & 0.00 & 0.00 & 0.00 & 0.00 \\
\hline -House shrew & 45.83 & 2.22 & 8.50 & 5.88 & 17.68 & 8.33 & 30.88 & 6.90 & 15.11 \\
\hline Invertebrates & & 48.89 & 4.08 & 52.94 & 3.47 & 54.17 & 4.38 & 48.28 & 2.31 \\
\hline Coleoptera & 1 & 2.22 & 0.19 & 17.65 & 1.16 & 8.33 & 0.67 & 3.45 & 0.16 \\
\hline Hemiptera & 1 & 15.56 & 1.30 & 0.00 & 0.00 & 8.33 & 0.67 & 10.34 & 0.49 \\
\hline Hymenoptera & 1 & 28.89 & 2.41 & 32.35 & 2.12 & 33.33 & 2.69 & 31.03 & 1.48 \\
\hline Orthoptera & 1 & 2.22 & 0.19 & 2.94 & 0.19 & 0.00 & 0.00 & 3.45 & 0.16 \\
\hline Scorpiones & 1 & 0.00 & 0.00 & 0.00 & 0.00 & 4.17 & 0.34 & 0.00 & 0.00 \\
\hline Unidentified plant matter & - & 4.44 & 0.00 & 0.00 & 0.00 & 0.00 & 0.00 & 0.00 & 0.00 \\
\hline Remnants of prey animals & & 45 & & 34 & & 24 & & 29 & \\
\hline Number of pellets & & 21 & & 16 & & 11 & & 15 & \\
\hline Mean no. of prey / pellet \pm SEM & & $2.14 \pm$ & & $2.13 \pm$ & .15 & $2.18 \pm$ & .23 & $1.93 \pm$ & \\
\hline
\end{tabular}

Table III. Seasonal changes in relative abundance (\% $\mathrm{N})$ and biomass $(\% \mathrm{~B})$ of prey items found in the diet of the spotted owlet (Athene brama) from the Wildlife Park Lohi Bher of Rawalpindi District, Pakistan.

\begin{tabular}{|c|c|c|c|c|c|c|c|c|c|}
\hline \multirow[t]{2}{*}{ Prey items } & \multirow{2}{*}{$\begin{array}{l}\text { Mean prey } \\
\text { mass (g) }\end{array}$} & \multicolumn{2}{|c|}{ Winter } & \multicolumn{2}{|c|}{ Spring } & \multicolumn{2}{|c|}{ Summer } & \multicolumn{2}{|c|}{ Autumn } \\
\hline & & $\% \mathrm{~N}$ & $\% \mathrm{~B}$ & $\% \mathrm{~N}$ & $\% \mathrm{~B}$ & $\% \mathrm{~N}$ & $\% \mathrm{~B}$ & $\% \mathrm{~N}$ & $\% \mathrm{~B}$ \\
\hline Mammals & & 34.40 & 90.33 & 38.51 & 76.84 & 31.87 & 89.60 & 54.64 & 92.39 \\
\hline Rodents & & 32.80 & 78.98 & 38.51 & 76.84 & 30.77 & 81.79 & 50.52 & 70.58 \\
\hline -Short-tailed bandicoot rat & 152.91 & 0.80 & 18.95 & 0.00 & 0.00 & 1.10 & 26.06 & 0.00 & 0.00 \\
\hline -House mouse & 12.11 & 32.00 & 60.03 & 38.51 & 76.84 & 29.67 & 55.73 & 50.52 & 70.58 \\
\hline \multicolumn{10}{|l|}{ Shrew } \\
\hline -House shrew & 45.83 & 1.60 & 11.36 & 0.00 & 0.00 & 1.10 & 7.81 & 4.12 & 21.81 \\
\hline \multicolumn{10}{|l|}{ Reptile } \\
\hline Unknown lizard & - & 0.00 & 0.00 & 0.00 & 0.00 & 1.10 & 0.00 & 0.00 & 0.00 \\
\hline \multicolumn{10}{|l|}{ Birds } \\
\hline -House Sparrow & 25 & 0.00 & 0.00 & 3.38 & 0.00 & 0.00 & 0.00 & 1.03 & 2.97 \\
\hline Unknown bird & - & 0.80 & 0.00 & 0.00 & 13.92 & 0.00 & 0.00 & 0.00 & 0.00 \\
\hline Invertebrates & & 62.40 & 9.67 & 56.08 & 9.24 & 67.03 & 10.40 & 40.21 & 4.64 \\
\hline Coleoptera & 1 & 40.00 & 6.20 & 42.57 & 7.01 & 37.36 & 5.80 & 27.84 & 3.21 \\
\hline Hemiptera & 1 & 7.20 & 1.12 & 6.76 & 1.11 & 19.78 & 3.07 & 9.28 & 1.07 \\
\hline Hymenoptera & 1 & 9.60 & 1.49 & 3.38 & 0.56 & 2.20 & 0.34 & 2.06 & 0.24 \\
\hline Orthoptera & 1 & 5.60 & 0.87 & 3.38 & 0.56 & 7.69 & 1.19 & 1.03 & 0.12 \\
\hline Unidentified invertebrates & - & 2.40 & 0.00 & 2.03 & 0.00 & 0.00 & 0.00 & 4.12 & 0.00 \\
\hline Remnants of prey animals & & 125 & & 148 & & 91 & & 97 & \\
\hline Number of pellets & & 72 & & 96 & & 53 & & 61 & \\
\hline Mean no. of prey / pellet \pm SEM & & $1.74 \pm$ & & $1.54=$ & 0.07 & $1.72 \pm$ & .09 & $1.59 \pm$ & .08 \\
\hline
\end{tabular}


Table IV. Relative abundance (\% N) and prey biomass (\% B) in the food of the eurasian eagle owl (Bubo bubo) across four seasons in the Wildlife Park Lohi Bher, Rawalpindi District, Pakistan.

\begin{tabular}{|c|c|c|c|c|c|c|c|c|c|}
\hline \multirow[t]{2}{*}{ Prey items } & \multirow{2}{*}{$\begin{array}{l}\text { Mean prey } \\
\text { mass (g) }\end{array}$} & \multicolumn{2}{|c|}{ Winter } & \multicolumn{2}{|c|}{ Spring } & \multicolumn{2}{|c|}{ Summer } & \multicolumn{2}{|c|}{ Autumn } \\
\hline & & $\% \mathrm{~N}$ & $\% \mathrm{~B}$ & $\% \mathrm{~N}$ & $\%$ B & $\% \mathrm{~N}$ & $\% \mathrm{~B}$ & $\% \mathrm{~N}$ & $\% \mathrm{~B}$ \\
\hline Mammals & & 76.19 & 99.82 & 77.42 & 99.87 & 80.45 & 99.90 & 73.17 & 99.39 \\
\hline Rodents & & 50.00 & 74.67 & 54.84 & 27.15 & 78.95 & 99.90 & 54.88 & 78.39 \\
\hline -Bandicoot rat & 170.04 & 2.38 & 6.06 & 4.84 & 8.26 & 17.29 & 38.74 & 0.00 & 0.00 \\
\hline -Indian bush rat & 48.5 & 1.59 & 1.15 & 1.61 & 0.79 & 8.27 & 5.28 & 0.00 & 0.00 \\
\hline Indian gerbil & 95.31 & 15.87 & 22.65 & 6.45 & 6.17 & 20.30 & 25.49 & 1.22 & 2.91 \\
\hline -Short-tailed bandicoot rat & 152.91 & 17.46 & 39.98 & 4.84 & 7.43 & 13.53 & 27.26 & 12.20 & 46.72 \\
\hline -Roof/house rat & 118 & 1.59 & 2.80 & 0.00 & 0.00 & 0.00 & 0.00 & 6.10 & 18.03 \\
\hline -House mouse & 12.11 & 11.11 & 2.01 & 37.10 & 4.51 & 19.55 & 3.12 & 35.37 & 10.73 \\
\hline \multicolumn{10}{|l|}{ Shrew } \\
\hline -House shrew & 45.83 & 25.40 & 17.43 & 19.35 & 8.90 & 0.00 & 0.00 & 18.29 & 21.00 \\
\hline \multicolumn{10}{|l|}{ Hare } \\
\hline -Indian hare & 1971.5 & 0.00 & 0.00 & 3.23 & 63.82 & 0.00 & 0.00 & 0.00 & 0.00 \\
\hline \multicolumn{10}{|l|}{ Mongoose } \\
\hline -Small Indian Mongoose & 650 & 0.79 & 7.72 & 0.00 & 0.00 & 0.00 & 0.00 & 0.00 & 0.00 \\
\hline \multicolumn{10}{|l|}{ Bats } \\
\hline Unknown microbats & - & 0.00 & 0.00 & 0.00 & 0.00 & 1.50 & 0.00 & 0.00 & 0.00 \\
\hline \multicolumn{10}{|l|}{ Reptiles } \\
\hline Unknown lizards & - & 6.35 & 0.00 & 9.68 & 0.00 & 3.76 & 0.00 & 1.22 & 0.00 \\
\hline \multicolumn{10}{|l|}{ Birds } \\
\hline Unknown birds & - & 5.56 & 0.00 & 0.00 & 0.00 & 2.26 & 0.00 & 1.22 & 0.00 \\
\hline Invertebrates & & 11.90 & 0.18 & 12.90 & 0.13 & 7.52 & 0.10 & 24.39 & 0.61 \\
\hline Coleoptera & 1 & 7.14 & 0.11 & 11.29 & 0.11 & 3.76 & 0.05 & 14.63 & 0.37 \\
\hline Hymenoptera & 1 & 4.76 & 0.07 & 1.61 & 0.02 & 2.26 & 0.03 & 9.76 & 0.24 \\
\hline Orthoptera & 1 & 0.00 & 0.00 & 0.00 & 0.00 & 1.50 & 0.02 & 0.00 & 0.00 \\
\hline Unidentified plant matter & - & 0.00 & 0.00 & 0.00 & 0.00 & 6.02 & 0.00 & 0.00 & 0.00 \\
\hline Remnants of prey animals & & 126 & & 62 & & 133 & & 82 & \\
\hline Number of pellets & & 37 & & 8 & & 26 & & 18 & \\
\hline Mean no. of prey / pellet \pm SEM & & $3.41 \pm$ & & $7.75 \pm$ & 37 & $5.12 \pm$ & & $4.56 \pm$ & \\
\hline
\end{tabular}

house shrew was eaten throughout the year except the summer season and contributed about $14.64 \%$ in diet. In addition, two hares $(3.23 \%)$ in spring, one mongoose $(0.79 \%)$ in winter and two microbats $(1.50 \%)$ in summer season were also consumed (Table IV). Arthropods were better consumed in terms of number (13.16\%). As far as the biomass of the owl's diet was concerned, rodents accounted for $73.71 \%$ of the diet of the owl, while mammals other than rodents accounted for $26.10 \%$. Thus, $99.81 \%$ of the diet of the eagle owl in the Wildlife Park Lohi Bher was due to mammalian preys and the remaining biomass of the owl's food was of arthropods $(0.19 \%)$ (Table I). Significant differences in the diet of eurasian eagle owl were recorded among seasons $\left(\chi^{2}(3)=23.965, P<0.05\right)$ with a mean rank prey item score of 233.79 for winter, 198.48 for spring, 165.56 for summer and 82 for autumn. Winter, spring and summer diets were not statistically different whereas winter and summer diets $(U=5516.50, P=0.000)$ and summer and autumn diets $(U=4161.50, P=0.003)$ were significantly variable. The values obtained by the IRI ranked short-tailed bandicoot rat as chief food among prey items (Table I).

Two of the murid rodents namely, short-tailed bandicoot rat- and house mouse along with Asian house shrew and insects of order Coleoptera, Hymenoptera and 
Orthoptera, were found consistently in the diet of three owl species (Table I). Overall murids and invertebrates were the dominant groups of prey items in each owl species diet. Food of three owl species was significantly different from each other $\left(\chi^{2}(2)=65.566, P<0.05\right)$ with a mean rank of prey items 549.07 for the spotted owlet, 585.92 for the collared owlet and 412.01 for the eurasian eagle owl. The spotted owlet consumed more prey items than that of the collared owlet $(\mathrm{U}=26715, \mathrm{P}=0.026)$ and eagle owl $(\mathrm{U}=65867, \mathrm{P}$ $=0.000)$. The food of the collared owlet was significantly different from that of the eagle owl $(\mathrm{U}=18769, \mathrm{P}=0.000)$. Mean number of prey items per pellet were 2.10 (SEM \pm 0.09 , range $=1-4)$ in case of the collared owlet and 1.63 $(\mathrm{SEM} \pm 0.04$, range $=1-4)$ in the spotted owlet. In the pellets of the eurasian eagle owl, mean prey items per pellet were $4.53(\mathrm{SEM} \pm 0.19$, range $=1-9)$. Strong positive correlation was observed between the body size of owl species in the study area and the number of prey items found in their pellets (Pearson correlation: $r=0.630, n=1834, P=0.000$ ).

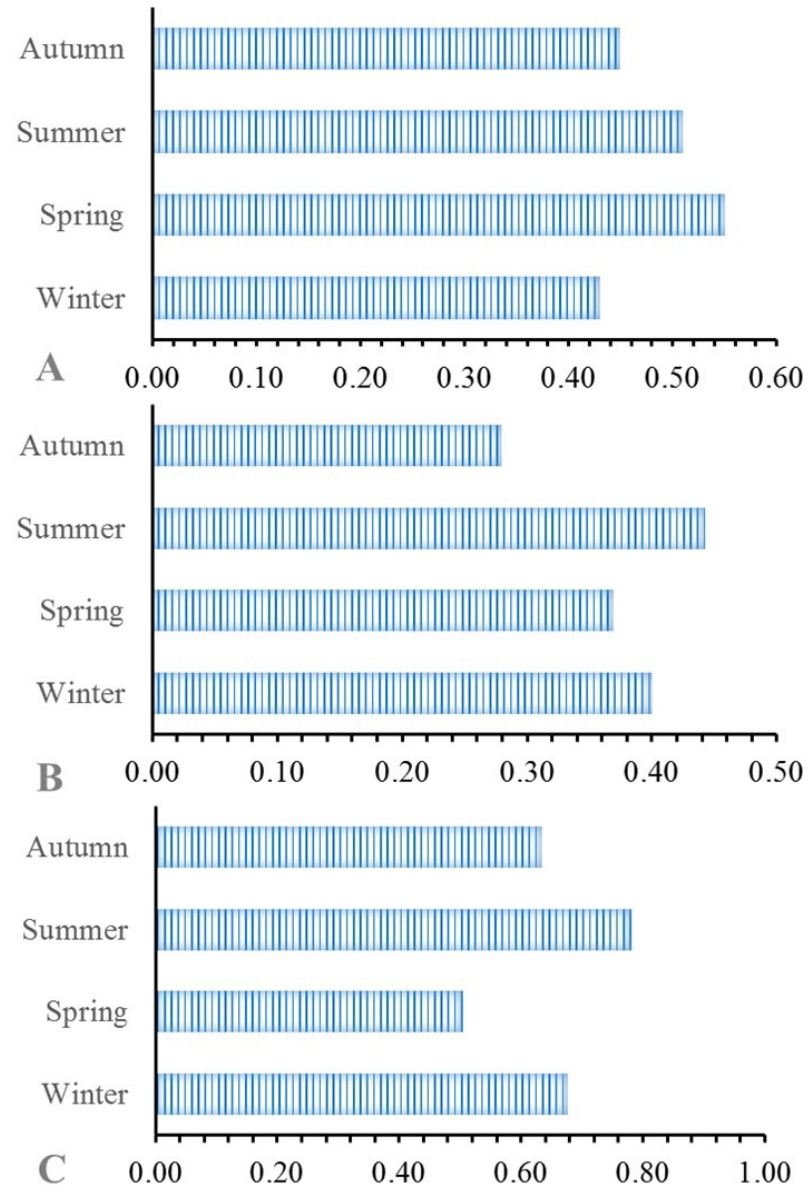

Fig. 4. Seasonal shift in the food niche breadth $\left(\mathrm{FNB}_{\mathrm{S}}\right)$ of collared owlet (A), spotted owlet (B) and eurasian eagle owl (C) in Wildlife Park Lohi Bher, Rawalpindi district, Pakistan.
The eurasian eagle owl's diet contained most diverse food $\left(\mathrm{H}^{\prime}=1.96, \mathrm{~S}=12\right)$ as compared to the collared owlet $\left(\mathrm{H}^{\prime}=1.79, \mathrm{~S}=11\right)$ and the spotted owlet $\left(\mathrm{H}^{\prime}=1.39, \mathrm{~S}\right.$ $=8)$. Peilou's evenness values indicated preference of the collared owlet $\left(\mathrm{J}^{\prime}=0.75\right)$, spotted owlet $\left(\mathrm{J}^{\prime}=0.67\right)$ and eurasian eagle owl $\left(\mathrm{J}^{\prime}=0.79\right)$ towards one prey item. Diversity indices reflected variable utilization of resources by all the three owl species in our study area (Fig. 3A-C). Food niche breadth of the eurasian eagle owl was observed more broader $\left(\mathrm{FNB}_{\mathrm{S}}=0.62\right)$ than that of the collared owlet $\left(\mathrm{FNB}_{\mathrm{S}}=0.34\right)$ and spotted owlet $\left(\mathrm{FNB}_{\mathrm{S}}=0.32\right)$. Seasonal food niche dynamics for the collared Owlet, spotted owlet and eurasian eagle owl are shown in Figures 4A, B, C.

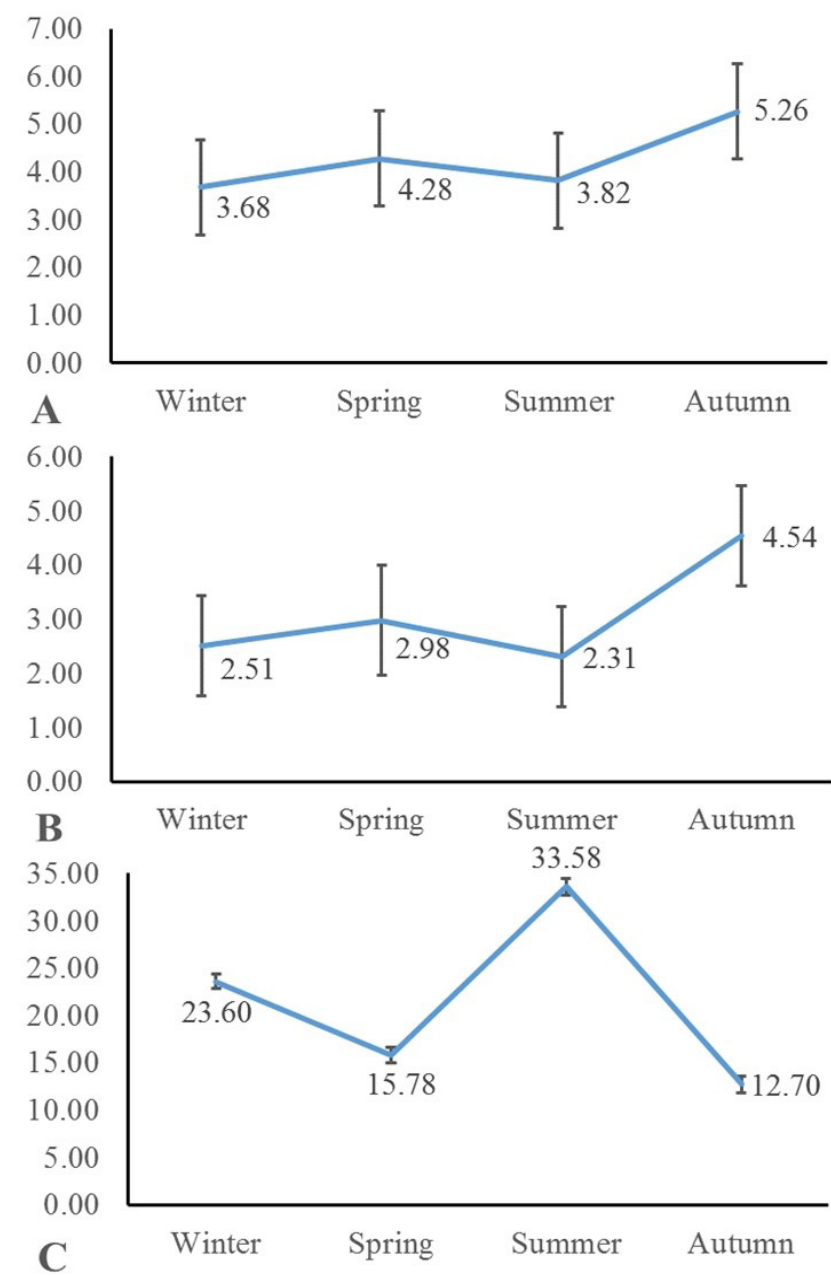

Fig. 5. Changes in geometric mean prey weight (GMPW) across four seasons in the diet of the collared owlet (A), spotted owlet (B) and eurasian eagle owl (C) in Wildlife Park Lohi Bher study area.

The geometric mean prey weight (GMPW) of the eurasian eagle owl $(21.78 \pm 0.71 \mathrm{~g})$ was significantly greater 
than that of the collared owlet $(4.18 \pm 0.75 \mathrm{~g})(t=-49.381$, $P<0.05)$ and spotted owlet $(2.95 \pm 0.87 \mathrm{~g})(t=-46.946, P<$ $0.05)$ whereas GMPW of collared owlet was significantly higher than that of the spotted owlet $(t=-3.542, P<0.05)$. Seasonal fluctuations of GMPW in the diet of the collared owlet, spotted owlet and eurasian eagle owl in our study area are shown in Fig. 5A, B, C. The spotted owlet captured smaller prey and eurasian eagle owl; a large-sized predator even took proportionately more smaller prey items whereas collared owlet consumed larger prey in relation to its body weight (Table V). We observed a statistically significant negative correlation between predator size and mass of the prey $(r=0.249, n=996, P=0.000)$.

Table V. Ratio between geometric mean prey weight (GMPW) and mean weight of the owl species in the Wildlife Park Lohi Bher, Rawalpindi district, Pakistan.

\begin{tabular}{llll}
\hline Owl species & $\begin{array}{l}\text { GMPW } \\
\text { (g) }\end{array}$ & $\begin{array}{l}\text { Mean predator } \\
\text { weight }(\mathbf{g})\end{array}$ & Ratio \\
\hline collared owlet & 4.18 & $57.5^{*}$ & 0.072 \\
spotted owlet & 2.95 & $112.5^{*}$ & 0.026 \\
Eurasian eagle owl & 21.78 & $2161^{* *}$ & 0.010 \\
\hline
\end{tabular}

* mean weight calculated from Roberts (1991); Konig and Weick (2008);

** mean weight taken from Cui et al. (2008).

Cluster analysis grouped different prey items consisting of similar proportional trends in the annual consumption of owls' diets. In the diet of the collared Owlet, house mouse and insect order Hymenoptera were consumed with similar proportions whereas the percentage of Indian gerbil encompassed a broader array of prey items' proportion round the year (Fig. 6A). In the spotted owlet's annual diet, the proportion of the house mouse alone was equivalent to all other taxa followed by the beetles of order Coleoptera whereas the percentage of house sparrow Passer domesticus was similar to that of the combined proportion of insects of the order Hymenoptera and Orthoptera. short-tailed bandicoot rat and Asian house shrew were obtained with similar annual arrangement by the owlet (Fig. 6B). Eurasian eagle owl consumed diverse taxa with proportionately large animals than that of the other two owlets. Cluster analysis revealed that the portion of Indian hare was part of the combined proportion of wide range of mammals and insects whereas the fraction of the small Indian mongoose was similar to that of the Orthoptera as least consumed prey items annually (Fig. 6C). High dietary overlap was observed between collared owlet and spotted owlet $(66.81 \%)$ followed by an overlap between, spotted owlet and eurasian eagle owl $(63.58 \%)$ and collared owlet and eurasian eagle owl (66.28 \%). Seasonal percent overlap among three oil species in our study area is depicted in Table VI.

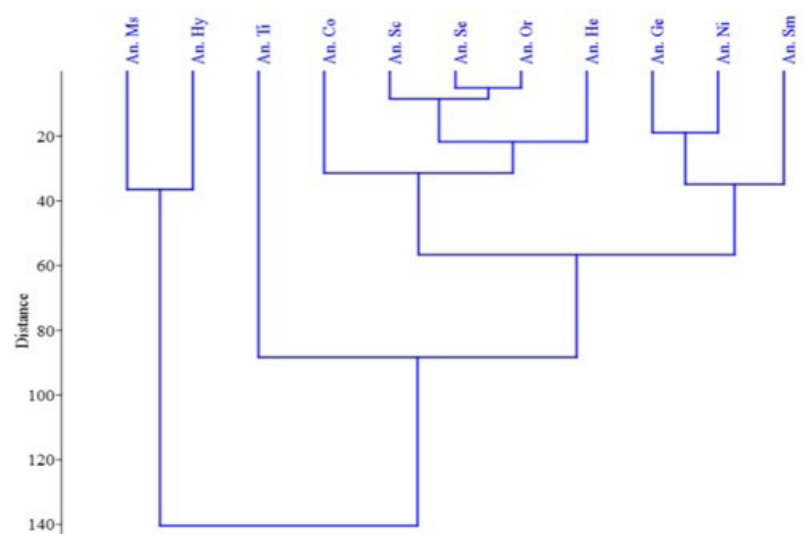

$\mathbf{A}$
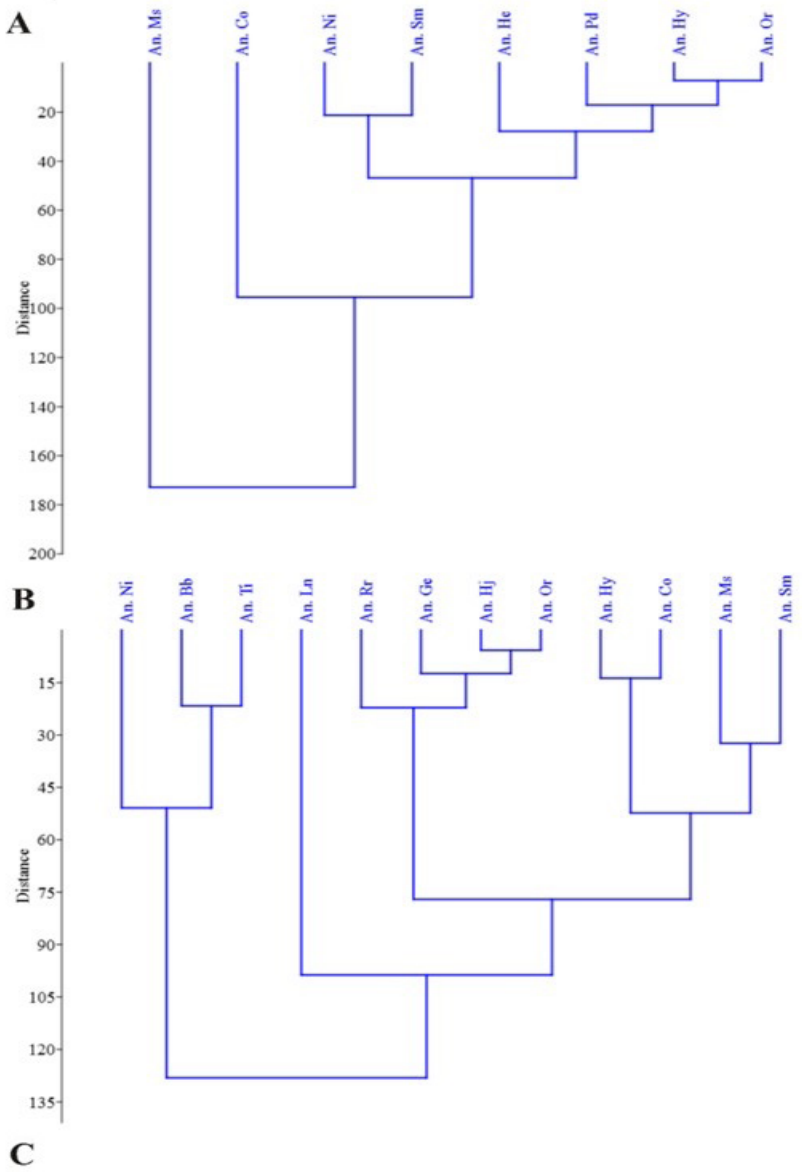

Fig. 6. Cluster analysis results on annual (An.) prey items' composition for (A) collared owlet $(n=11)$, (B) spotted owlet $(n=8)$, and $(\mathrm{C})$ eurasian eagle owl $(n=12)$, where proportional values of $\% \mathrm{~N}, \% \mathrm{~B}$ and $\% \mathrm{~F}$ were used as quantitative characteristics for each prey item (Bb, Bandicota bengalensis; Co, Coleoptera; Ge, Golunda ellioti; He, Hemiptera; Hj, Herpestes javanicus; Ln, Lepus nigricollis; Ms, Mus musculus; Ni, Nesokia indica; Or, Orthoptera; Pd, Passer domesticus; Rr, Rattus rattus; Sc, scorpion; Se, Suncus etruscus; Sm, Suncus murinus; Ti, Tatera indica). 
Table VI. Seasonal percent dietary overlap $\left(\% O_{\mathrm{i}, \mathrm{j}}\right)$ among the three species of owls in the Wildlife Park Lohi Bher, Rawalpindi district, Pakistan.

\begin{tabular}{llll}
\hline Seasons & $\begin{array}{l}\text { collared owlet } \\
\text { and spotted owlet }\end{array}$ & $\begin{array}{c}\text { collared owlet and } \\
\text { eurasian eagle owl }\end{array}$ & $\begin{array}{l}\text { spotted owlet and } \\
\text { eurasian eagle owl }\end{array}$ \\
\hline Winter & 60.29 & 38.25 & 37.3 \\
Spring & 72.99 & 71.72 & 74.03 \\
Summer & 59.61 & 45.92 & 38.9 \\
Autumn & 67.86 & 76.46 & 85.59 \\
Annual & 66.81 & 66.28 & 63.58 \\
\hline
\end{tabular}

\section{DISCUSSION}

Collared owlets have been described as solitary hunters (Roberts, 1991). With crepuscular activity pattern, they had been observed killing birds of genera: Garrulax and Orthotomus (Whistler, 1930), and consuming insects of order Melolonthinae (Roberts, 1991). In the present study, about $90 \%$ of food items of the collared owlet came from house mouse, shrews and insects. Pellet size of the owlet was smaller than that of the sympatric spotted owlet in the study area. About half of the numerically expressed food of owlet was due to insects. Among four species of murid rodents, Indian gerbil, house mouse and insect orders Coleoptera, Hymenoptera and Orthoptera were consumed throughout the year while birds were not found in seasonal diet, instead Asian house shrew was the other source of food in the owlet's diet in our study area. In terms of biomass, mammals contributed more than $96 \%$ in the diet of the collared owlet in the present study (Table I). Ratio between geometric mean prey weight of the owlet and body weight of the owlet supported earlier observations on similar sized owlets suggesting that the predation of the owlet on proportionately larger preys than their own body weight (Mikusek et al., 2001; Motta-Junior, 2007). We also found fractions of a scorpion during summer season. Pande et al. (2004) in India also observed scorpions in spotted owlet's diet and suggested that scorpions could not be considered as food of choice when they were represented with the relative abundance of less than $1 \%$ in owlet's diet. We did not find seasonal differences in the diet of the collared owlet perhaps due to small seasonal sample size of pellets.

Mahmood-Ul-Hassan et al. (2007b) studied the diet of the spotted owlet in agriculture-based ecosystem and reported insects as major remnants by number and rodents as staples with house mouse and soft-furred field rat Millardia meltada in central Punjab of Pakistan. In present research, that was carried out in uncultivated area surrounded by human anthropogenic activities, house mouse was identified as main food item of spotted owlet supplemented with four insect orders including Coleoptera, Hemiptera, Hymenoptera and Orthoptera in all seasons. Vanitha et al. (2018) reported that spotted owlet nests were found frequently near to human habitations and their diet was bulked with insects than mammals. Pande et al. (2007) found considerable number of rodents and insects in the diet of spotted owlet in urban uncultivated lands of India. However, the spectrum of rodents in the diet of spotted owlet in present study was not as broader as that of the collared owlet rather it was contributed by small quantum of food obtained from avian and reptilian source. This has also been reflected in the values of food niche breadth and diversity indices of both owlet species in our study area. The results of the present study are in consistence with the earlier studies on food habits of the spotted owlet in Pakistan (Tariq et al., 2003; Shah et al., 2004; MahmoodUl-Hassan et al., 2007b; Nadeem et al., 2012).

Eurasian eagle owl has been reported to be an opportunistic predator that prefers to consume prey species of high body mass (Amr et al.,1997; Cui et al., 2003; Shehab, 2004; Loveras et al., 2009; Sándor and Ionescu, 2009; Tobajas et al., 2015; Amr et al., 2016; Milchev, 2016). This owl has been observed to shift to even smaller prey species depending on their availability in nest proximity (LourenÇo, 2006; Tobajas et al., 2015). The most important taxa of prey species consumed by the eagle owl in our uncultivated study area consisted of murids. Among six species of rodents identified in the eagle owl's diet in our study area, three species including house mouse, shorttailed bandicoot rat and Indian gerbil were used as a food source in four seasons. In northern areas of Pakistan, nonhibernating migratory hamster (Cricetulus migratorius) was recorded as principal source of food whereas Afghan hedgehog, Hemiechinus auritus megalotis and Persian jird, Meriones persicus were the staples in the eagle owl's diet in Balochistan (Roberts, 1991). In Sindh province, an analysis of 35 pellets revealed six small mammal species viz. shorttailed bandicoot rat, Indian gerbil, soft-furred field rat, house rat, Balochistan gerbil, Gerbillus nanus and Anderson's shrew, Suncus stoliczkanus, along with two insects of the order Coleoptera and Orthoptera. Papageorgiou et al. (1993) found more mammals particularly rodents in the diet of the eagle owl in forested habitat of north-eastern Greece. The unexpected fractions of insects along with mammals were also found in the eagle owl's diet in the present study as had been reported in earlier studies (Baumgart, 1975; Hiraldo et al., 1975; Rifai et al., 2000). Insects in the food of the large-sized predator throughout the year might suggest that they had some nutritive value (Papageorgiou et al., 1993) or they mechanically assisted digestion process (Pande et al., 2004). Lizards of unknown taxa were also found during four seasons in the eagle owl's diet in the study area. Silva- 
Porto and Cerqueira (1990) explained that the activity times and breeding periods of lizards made them vulnerable for owls as activity times of nocturnal lizards coincided with that of owls and breeding times increased their number. We found two Indian hare in spring season only, as they were of highest mass carrying prey items, in the diet of the eagle owl and proportionally they were represented after murids in terms of biomass. Tumurbat et al. (2009) argued that mammals with higher body weight were over represented in eagle owls' diet. We present index of relative importance values to overcome numerical and biomass contribution errors of prey items in the eagle owls' diet. Zahler and Dietemann (1999) had also reported predation on Cape hare Lepus capensis by the eagle owl in Himalayan region of Pakistan. The eurasian eagle owls of our study area captured smaller preys in relation to their body weight. Kondratenko and Tovpinets (2001) supported our findings that the eagle owls prefer to capture easily accessible lightweight, small to medium-sized mammals and birds. We also found a single individual of the small Indian mongoose in winter pellets of the eurasian eagle owl in the study area. Predation of eagle owl on mongoose has been reported in Adriatic islands of Yugoslavia (Tvrtkovic and Krystufek, 1990; Cavallini and Serafini, 1995). We found both nests of the eurasian eagle owl in close proximity to the edge of human inhabitations that might enhance encounter rate with mongoose during winter season, when rodent food would be less available. Many of the rodents in Pothwar plateau including our study area, and especially those dominant in the owl's food, bred round the year excluding two to three winter months of the year. These fossorial rodents generally stop breeding from the end of November to mid-February but the exact period of their reproductive silence has not considered stable and generally depends on the severity of the cold season (Hussain et al., 2003). We found two microbats in the eurasian eagle owl's diet during summer season. Lesiński et al. (2009) stated that owls nesting in edge habitats would have more probability of encountering with bats because of their roosts in human settlements and their commuting and foraging activities in wild habitats. Variations in prey preference of owls had been found directly related to encounter rate and abundance of prey species and that in turn directly related to the preys' reproduction patterns (Marti, 1974; Bose and Guidali, 2001).

Selection of the prey by owls is controlled by a most obvious limiting factor, and that is the body size of not only of the prey species but the predators as well (Marti, 1974; Mahmood-ul-Hassan et al., 2007b). Predators with large bodies consume prey species with diverse body size as compared to predators of smaller body size (Cohen et al., 1993) and selectivity of prey species might be due to variations in timings of prey activity (Trejo and Guthmann,
2003).

Pellet size of the collared owlet, spotted owlet and eurasian eagle owl in our study area varied round the year and was according to the description given by Marti (1974) who related pellet morphometrics to the diet ingredients and the nutrition acquired. We found the highest number of prey items per pellet as compared to other studies (Amr et al., 1997; Amr et al., 2016) from the eurasian eagle owl. The collared owlet, spotted owlet and eurasian eagle owl had high dietary overlap. Mehta et al. (2018) concluded that high overlap between asynchronous raptors might be due to hunting activity in the same habitat and adoption of "sit and wait" strategy.

\section{CONCLUSION}

We found high proportions of murid rodents along with insects in the foods of differential body sized owls. Food of owls consisting of rodents was not a new finding of the present study rather a high frequency of rodents' consumption in wild area suggested that these nocturnal and crepuscular raptors had strong preferences for rodents. A similar study with variable sized owl species in association with the cultivated land might help to develop a clear picture about the ecological significance of these avian predators as rodent pest controlling agents in Pakistan.

\section{ACKNOWLEDGEMENTS}

We are thankful to the officials and field staff of the Wildlife Park Lohi Bher Rawalpindi for their support in the collection of pellets. This study was partially supported by Pakistan Science Foundation (PSF) and Higher Education Commission (HEC) of Pakistan. The funding organizations had no contribution in data collection and its analysis, planning and design of the study, decision to publish, or development of the manuscript.

\section{Statement of conflict of interest}

The authors have declared no conflict of interest.

\section{REFERENCES}

Ahmad, S.S. and Ehsan, H., 2012. Analyzing the herbaceous flora of Lohi Bher Wildlife Park under variable environmental stress. Pak. J. Bot., 44: 1114.

Akhtar, N. and Beg, M.A., 1985. Food habit of owls in the Punjab. Pak. J. agric. Sci., 22: 200-205.

Ali, S. and Ripley, S.D., 1987. Compact handbook of the birds of India and Pakistan. Oxford University Press London, pp. 737 
Amr, Z.S., Al-Melhim, W. N. and Yousef, M.A., 1997. Mammal remains from pellets of the Eagle owl, Bubo bubo, from Azraq Nature Reserve, Jordan. Zool. Middle East, 14: 5-10. https://doi.org/10.1080/ 09397140.1997.10637698

Amr, Z.S., Handal, E.N., Bibi, F., Najajrah, M.H. and Qumsiyeh, M.B., 2016. Change in diet of the Eurasian eagle owl (Bubo bubo) suggests decline in biodiversity in Wadi Al Makhrour, Bethlehem Governorate, Palestinian Territories. Slovak Raptor J., 10: 75-79. https://doi.org/10.1515/srj-2016-0002

Aragón, E., Castillo, B. and Garza, A., 2002. Rodents in the diet of two nocturnal raptors (Bubo virginianus and Tyto alba) in the northeast of Durango, México. Acta Zool. Mexic., 86: 29-50.

Balčiauskas, L. and Balčiauskienè, L., 2014. Selective predation on common voles by Tawny Owls and Long-eared Owls in winter and spring. Turk. J. Zool., 38: 242-249. https://doi.org/10.3906/zoo-1303-20

Baumgart, W., 1975. At Horsten of Uhus (Bubo bubo) in Bulgaria. II. The eagle owl in northeast Bulgaria (Aves, Strigidae). Zool. Abhandl. Mus. Tierk. Dresden, 33: 251-275.

Beg, M.A., Maqbol, M. and Mushtaq-Ul-Hassan, M., 1990. Food habits of the spotted owlet, Athene brama. Pak. J. agric. Sci., 27: 127-131.

BirdLife International, 2018. IUCN red list for birds. Available at http://www.birdlife.org (accessed 31 August 2018).

Bose, M. and Guidali, F., 2001. Seasonal and geographic differences in the diet of the barn owl in an agroecosystem in northern Italy. J. Raptor Res., 35: 240246.

Capizzi, D. and Luiselli, L., 1998. A comparative study of the variability of owl diets in three localities of central Italy. Rev. Ecol., 53: 367-385.

Cavallini, P. and Serafini, P., 1995. Winter diet of the small Indian mongoose, Herpestes auropunctatus, on an Adriatic island. J. Mammal., 76: 569-574. https://doi.org/10.2307/1382365

Cichocki, J., Gabryś, G. and Ważna, A., 2008. Winter food of the barn owl Tyto alba (Scopoli, 1769), the tawny owl Strix aluco Linnaeus, 1758 and the longeared owl Asio otus (Linnaeus, 1758) co-occurring in the Silesian Lowland. Scientific papers of Wroclaw University of Environmental and Life Sciences. Biol. Anim. Breed., 56: 19-30.

Cohen, J.E., Pimm, S.L., Yodzis, P. and Saldaña, J., 1993. Body sizes of animal predators and animal prey in food webs. J. Anim. Ecol., 62: 67-78. https://doi. org $/ 10.2307 / 5483$

Cui, Q., Su, J. and Jiang, Z. 2008. Summer diet of two sympatric species of raptors upland buzzard (Buteo hemilasius) and Eurasian eagle owl (Bubo bubo) in Alpine meadow: Problem of coexistence. Polish J. Ecol., 56: 173-179.

Cui, Q., Lian, X., Zhang, T. and Su, J., 2003. Food Habits Comparison between Buteo hemilasius and Bubo bubo. Chinese J. Zool., 38: 57-63.

Hart, R.K., Calver, M.C. and Dickman, C.R. 2002. The index of relative importance: an alternative approach to reducing bias in descriptive studies of animal diets. Wildl. Res., 29: 415-421. https://doi. org/10.1071/WR02009

Hayward, G.D. and Garton, E.O., 1988. Resource partitioning among forest owls in the River of No Return Wilderness, Idaho. Oecologia, 75: 253-265. https://doi.org/10.1007/BF00378606

Hiraldo, F. andrada, J. and Parreño, F.F., 1975. Diet of the eagle owl (Bubo bubo) in Mediterranean Spain. Doñana Acta verteb., 2: 161-177.

Hurlbert, S.H., 1978. The measurement of niche overlap and some relatives. Ecology, 59: 67-77. https://doi. org/10.2307/1936632

Hussain, I., Cheema, A.M. and Khan, A.A., 2003. Small rodents in the crop ecosystem of Pothwar Plateau, Pakistan. Wildl. Res., 30: 269-274. https://doi. org/10.1071/WR01025

Jaksić, F.M., 1982. Inadequacy of activity time as a niche difference: the case of diurnal and nocturnal raptors. Oecologia, 52: 171-175. https://doi.org/10.1007/ BF00363832

Kayahan, A. and Tabur, M.A., 2016. Diet composition of Little Owl (Athene noctua Scopoli, 1769) in Turkey. Pakistan J. Zool., 48: 943-948.

Kayani, S.B., Anwar, M., Ashfaq, M., Hussain, I. and Mahmood, T., 2015. Morphometric studies of the fresh water turtles from Rawalpindi Islamabad region of Pakistan. J. Biodiver. environ. Sci., 6: 228233.

Kondratenko, A.V. and Tovpinets, N.N., 2001. Mammals in the Diet of Owls from the Donetsk-Don and Donetsk-Azov Steppes. Vestn. Zool., 35: 95-98.

Konig, C. and Weick, F., 2008. Owls of the world. London: Christopher Helm, an imprint of A and C Black publishers Ltd.

Leonardi, G. and Arte, G.L.D., 2006. Food habits of barn owl (Tyto alba) in steppe area of Tunisia. J. Arid Environ., 65: 677-681. https://doi.org/10.1016/j. jaridenv.2005.10.007

Lesiński, G., Gryz, J. and Kowalski, M., 2009. Bat predation by tawny owls Strix aluco in differently human-transformed habitats. Italian J. Zool., 76: 415421. https://doi.org/10.1080/11250000802589535 
Levins, R., 1968. Evolution in changing environments. Monograph in Population Biology, Vol. 2. Princeton University Press, Princeton.

Loveras, L., Moreno-García, M. and Nadal, J., 2009. The eagle owl (Bubo bubo) as a leopard remains accumulator: taphonomic analysis of modern rabbit remains recovered from nests of this predator. Int. J. Osteoarchaeol., 19: 573-592. https://doi. org/10.1002/oa.995

LourenÇo, R., 2006. The food habits of Eurasian eagle-owls in Southern Portugal. J. Raptor Res., 40: 297-300. https://doi.org/10.3356/08921016(2006)40[297:TFHOEE]2.0.CO;2

Mahmood-Ul-Hassan, M., Beg, M.A., MushtaqUl-Hassan, M. and Rana, S.A., 2007a. Nesting and breeding habits of the spotted owlet (Athene brama) in Punjab, Pakistan. J. Raptor Res., 41: 50-52. https://doi.org/10.3356/08921016(2007)41[50:NABHOT]2.0.CO;2

Mahmood-Ul-Hassan, M., Beg, M. A., Mushtaq-UlHassan, M. and Rana, S.A., 2007b. Food habits of the spotted owlet Athene brama in central Punjab, Pakistan. Acta Zool. Sin., 53: 64-69.

Marti, C.D., 1974. Feeding ecology of four sympatric owls. Condor, 76: 61-65. https://doi.org/10.2307/1365983

Marti, C.D., Bechard, M. and Jaksic, F.M., 2007. Food habits. In: Raptor research and management techniques (eds. D.M. Bildstein, K.L. Barber, and A. Zimmerman). Hancock House Publishers Ltd. pp. 129-153.

Martin, G.R., Twigg, L.E. and Robinson, D.J., 1996. Comparison of the diet of feral cats from rural and pastoral western Australia. Wildl. Res., 23: 475-484. https://doi.org/10.1071/WR9960475

Mehta, P., Kulkarni, J., Talmale, S. and Chandarana, R., 2018. Diets of sympatric forest owlets, spotted owlets, and jungle owlets in east Kalibhit forests, Madhya Pradesh, India. J. Raptor Res., 52: 338-348. https://doi.org/10.3356/JRR-17-00002.1

Mikusek, R., Kloubec, B. and Obuch, J., 2001. Diet of the pygmy owl (Glaucidium passerinum) in eastern Central Europe. Buteo, 12: 47-60.

Milchev, B., 2016. Dietary comparison of coexisting barn owl (Tyto alba) and eagle owl (Bubo bubo) during consecutive breeding seasons. Anim. Biol., 66: 219228. https://doi.org/10.1163/15707563-00002499

Motta-Junior, J.C., 2007. Ferruginous pygmy-owl (Glaucidium brasilianum) predation on a mobbing fork-tailed flycatcher (Tyrannus savana) in southeast Brazil. Biota Neotr., 7: 321-324. https://doi. org/10.1590/S1676-06032007000200038

Mushtaq-Ul-Hassan, M., Ghazi, R.R. and Noor-Un-
Nisa, 2007. Food preference of the short-eared owl (Asio flammeus) and barn owl (Tyto alba) at Usta Muhammad, Baluchistan, Pakistan. Turk. J. Zool., 31: 91-94.

Mushtaq-Ul-Hassan, M., Gill, A., Dar, B. and Khan, M.I., 2003. Diet of the little spotted owl (Athene brama) from Faisalabad and Sheikhupura, Pakistan. Acta Zool. Bulg., 55: 53-58.

Nadeem, M.S., Imran, S.M., Mahmood, T., Kayani, A.R. and Shah, S.I., 2012. A comparative study of the diets of barn owl (Tyto alba) and spotted owlet (Athene brama) inhabiting Ahmadpur East, Southern Punjab, Pakistan. Anim. Biol., 62: 13-28. https://doi. org/10.1163/157075511X597593

Nakazawa, T., 2017. Individual interaction data are required in community ecology: A conceptual review of the predator-prey mass ratio and more. Ecol. Res., 32: 5-12. https://doi.org/10.1007/s11284016-1408-1

Pande, S., Pawashe, A., Bastawade, D.B., and Kulkarni, P.P. 2004. Scorpions and molluscs: some new dietary records for spotted owlet Athene brama in India. Newsl. Ornithol., 1: 68-70.

Pande, S., Pawashe, A., Mahajan, M.N., Joglekar, C. and Mahabal, A., 2007. Effect of food and habitat on breeding success in spotted owlets (Athenebrama) nesting in villages and rural landscapes in India. $J$. Raptor Res., 41:26-34. https://doi.org/10.3356/08921016(2007)41[26:EOFAHO]2.0.CO;2

Papageorgiou, N.K., Vlachos, C.G. and Bakaloudis, D.E. 1993. Diet and nest site characteristics of eagle owl (Bubo bubo) breeding in two different habitats in north-eastern Greece. Avocetta, 17: 49-54.

Pianka, E.R., 1973. The structure of lizard communities. Annu. Rev. Ecol. System., 4: 53-74. https://doi. org/10.1146/annurev.es.04.110173.000413

Pielou, E.C., 1966. The measurement of diversity in different types of biological collections. J. Theoret. Biol., 13: 131-144. https://doi.org/10.1016/00225193(66)90013-0

Pinkas, L., 1971. Food habits study. Fish. Bull., 152: 5-10.

PMD, 2015. Pakistan Metrological Department data2015. Islamabad.

Qureshi, G., Malik, S. and Dilawar, A., 2012. Effect of experimental variation of temperature on serum triglycerides in Uromastyx hardwickii. Pakistan J. Physiol., 8: 13-14.

Rifai, L.B., Al-Melhim, W.N., Gharaibeh, B.M. and Amr, Z.S., 2000. The diet of the desert eagle owl, Bubo bubo ascalaphus, in the eastern desert of Jordan. $J$. Arid Environ., 44: 369-372. https://doi.org/10.1006/ 
jare.1999.0601

Roberts, T.J., 1991. Birds of Pakistan Vol. I. Oxford University Press Karachi. pp 598.

Roberts, T.J. 1997. Mammals of Pakistan (revised Ed.). Oxford University Press Karachi. pp. 525

Sándor, A.D. and Ionescu, D.T., 2009. Diet of the eagle owl (Bubo bubo) in Braşov, Romania. North-Western J. Zool., 5: 170-178.

Shah, Z.A., Beg, M.A. and Khan, A.A., 2004. Prey preferences of the spotted little owl (Athene barma) in the croplands near Faisalabad, Pakistan. Int. J. Agric. Biol., 6: 278-280.

Shannon, C.E., 1948. A mathematical theory of communication. Bell. System. Techn. J., 27: 379-423. https://doi.org/10.1002/j.1538-7305.1948.tb01338.x

Shehab, A.H., 2004. Diet of the eagle owl, Bubo bubo, in Syria. Zool. Middle East, 33: 21-26. https://doi.org/1 0.1080/09397140.2004.10638060

Silva-Porto, F. and Cerqueira, R., 1990. Seasonal variation in the diet of the burrowing owl Athene cunicularia in a restinga of Rio de Janeiro state. Ciên. Cult., 42: 1182-1186.

Tariq, S.A., Ghazi, R.R. and Noor-Un-Nisa, 2003. Study on the food of spotted owlet (Athene brama) at an agricultural farm, Gharo, lower Sindh. Pakistan. $J$. nat. Hist. Wildl., 2: 31-33.

Tobajas, J., Fernandez-de-Simon, J., Díaz-Ruiz, F., Villafuerte, R. and Ferreras, P., 2015. Functional responses to changes in rabbit abundance: Is the eagle owl a generalist or a specialist predator? Eur. J. Wildl. Res., 62: 85-92. https://doi.org/10.1007/ s10344-015-0976-7
Trejo, A. and Guthmann, N., 2003. Owl selection on size and sex classes of rodents: Activity and microhabitat use of prey. J. Mammal., 84: 652-658. https://doi. org/10.1644/1545-1542(2003)084<0652:OSOSAS> 2.0.CO;2

Tumurbat, J., Sundev, G. and Yosef, R., 2009. Nest site and food composition of the eagle owl Bubo bubo in Mangolia. Ardea, 97: 519-523. https://doi. org/10.5253/078.097.0417

Tvrtkovic, N. and Krystufek, B., 1990. Small Indian mongoose Herpestes auropunctatus (Hodgson, 1836) on the Adriatic Islands of Yugoslavia. Bonner Zool. Beit., 41: 3-8.

Vanitha, V., Thiyagesan, K. and Baskaran, N., 2018. Does southern spotted owlet Athene brama brama (Temminck, 1821) serve as a bio-control agent of agricultural pests? A case study from Cauvery Deltaic Region of Southern India. In: Indian hotspots: Vertebrate faunal diversity, conservation and management (eds. C. Sivaperuman and K. Venkataraman), Vol. 2, Springer, Singapore. pp. 139149. https://doi.org/10.1007/978-981-10-6983-3_7

Whistler, H., 1930. The birds of the Rawalpindi District, N. W. India. Part II. Ibis, 72: 247-279. https://doi. org/10.1111/j.1474-919X.1930.tb03625.x

Zahler, P. and Dietemann, C.D., 1999. A note on the food habits of eurasian eagle owl Bubo bubo in Northern Pakistan. Forktail, 15: 98-99.

Zuberogoitia, I., 2002. Eco-ethology of the nocturnal raptor community of Bizkaia. Ph.D. thesis, University of the Basque, Spain. 